\title{
Aptness of entomogenus fungi with diatomaceous earth against various stored grain insect pests
}

\author{
Ch. Muhammad Shahid Hanif ${ }^{1}$, Muhammad Zeeshan Mansha ${ }^{*}$, Hafiz Muhammad Aatif ${ }^{1}$, Qamar uz Zaman², \\ Muhammad ljaz', Kamran Ikram³ ${ }^{3}$ Azhar Abbas Khan ${ }^{1}$, Muhammad Ismail ${ }^{1}$ and Muhammad Ashir ${ }^{1}$
}

\begin{abstract}
Background: Numerous biotic and abiotic factors are responsible for losses of grains quality and quantity during storage. Insecticides used to control stored grain insect pests are not only hazardous to mammals and environment but also induce resistance in insect pests towards these synthetic chemicals. A current trial was conducted, during 2020, in a stored grain laboratory at the College of Agriculture, BZU, Bahadur Sub Campus, Layyah, Punjab, Pakistan. A diatomaceous earth (DE) formulation enhanced with bitterbarkomycin (DEBBM) and combined with Beauveria bassiana (Balsamo) Vuillemin was evaluated against Cryptolestes ferrugineus, (Stephens) (Coleoptera: Laemophloeidae), Rhyzopertha dominica (F.) (Coleoptera: Bostrichidae) and Tribolium castaneum (Coleoptera: Tenebrionidae) under laboratory conditions.
\end{abstract}

Results: DEBBM was applied at the rate of $50 \mathrm{mg} / \mathrm{kg}, \mathrm{DE}(150 \mathrm{mg} / \mathrm{kg})$ and Beauveria bassiana $\left(1.5 \times 10^{8}\right.$ and $1.5 \times 10^{10}$ conidia/kg) alone as well as in combination with wheat, rice and maize. Treated adult mortality was recorded at 7, 14 and 21 days after exposure. Results of the current study showed that insect pest mortality was maximum in the case of combined application of DEBBM with B. bassiana (high concentration) at prolonged exposure time as compared to their alone application. Mortality of $C$. ferrugineus was maximum in wheat and rice (100\%) over maize (97\%), while, $R$. dominica exhibited high mortality in wheat (100\%) followed by rice (97\%) and maize (94\%) at combined application of DEBBM with B. bassiana (high concentration) after 21 days. Regarding T. castaneum mortality was high in wheat (100\%) followed by rice (93\%) and maize (88\%) in case of combined application of DEBBM with B. bassiana (high concentration) at prolonged exposure time (21 days).

Conclusion: In crux, the current trial showed that a mixture of DEBBM and B. bassiana is helpful in controlling tested insect pests.

Keywords: Diatomaceous earth (DE) formulation, DE with Bitterbarkomycin (DEBBM), Beauveria bassiana, Stored commodities

\section{Background}

Wheat (Triticum aestivum L.) (Family: Poaceae) is considered as a chief staple food among all cereal grains and Pakistan stands production and consumption wise at the

\footnotetext{
*Correspondence: mianzeeshan121@gmail.com

${ }^{1}$ College of Agriculture, Bahauddin Zakariya University, Bahadur Sub

Campus, Layyah 31200, Punjab, Pakistan

Full list of author information is available at the end of the article
}

8th level (Shuaib et al. 2007). Wheat covers $37 \%$ of the total cultivated area in the country (Jilani 2007). Rice is the second chief food of Pakistan that covers $11 \%$ of the food production area and is cultivated on more than 2.5 million hectares (Chaudhry 1994). Maize (Zea mays L.) is also considered a food crop after wheat and rice. The Annual cultivation of maize is more than one million hectares (GOP 2003). 
Rhyzopertha dominica (F.) (Coleoptera: Bostrichidae) female lays eggs externally on wheat kernel, while, larvae feed and pupate inside the kernel. (Athanassiou et al. 2011). Cryptolestes ferrugineus (Stephens) (Coleoptera: Laemophloeidae) is primary stored grain pest which attack germs of seed. This insect has white color having size $3 \mathrm{~mm}$ in length (Mason 2003). Tribolium castaneum (Coleoptera: Tenebrionidae) is secondary pest of stored grain. Both larval and adult stages cause damage and complete life cycle on grain (Karunakaran et al. 2004).

Numerous biotic factors are responsible for losses of grains quality and quantity during storage (Ahmed et al. 2008). Therefore, grain storage losses due to insects may increase $10-20 \%$ in Pakistan (Khan et al. 2010). In extreme conditions, losses may occur up to $25.5 \%$ (Irshad et al. 1988). Stored grains or products are attacked by the most important 23 species and $75 \%$ from all these species are belong to only one order Coleoptera (Viñuela et al. 1993).

For the preservation of stored grains since the 1950s, synthetic residual insecticides have been used to control stored grain insect pests. Continuous use of these insecticides had made the insect pest resistant to these chemicals. Additionally, these chemicals are also toxic to animal and hazardous to the environment (Pacheco et al. 1990; Arthur 1996). Now a days the use of new chemistry products is prevailing all over the world. Because these have lower mammalian toxicity and can control the insects effectively. Different insect pest of field crops can be effectively controlled by the use of bio-nicotine pesticides (Ye et al. 2014).

Fungi are considered biocontrol agents against insects and produce spores that cause insect mortality by penetration into the body of insects (Goettel et al. 2005). $B$. bassiana can be used as a component in integrated pest management (IPM). For birds, plants and mammals $B$. bassiana is considered ecologically non-toxic (El-Sharabasy 2015). B. bassiana is found in soil and decaying plant debris. Its conidia penetrate the body of the insect, by stimulating its growth and it generates a strong contact with the body layer of the host insect (Holder and Keyhani 2005). So, the fungus is a good choice in IPM, as insects have gained resistance against chemicals and other substances. The $B$. bassiana is tested against various pests on cereal crops as a biological agent (Bounechada and Doumandji 2004). B. bassiana has the advantage that it controls diseases by disease causing vectors of various arthropods and serves as entomopathogenic fungus (Stricker et al. 2006). Different scientists worked on the mutual effect of DE and entomopathogenic fungus (Riasat et al. 2011), or chemical insecticides and entomopathogenic fungus (Srivastava et al. 2009), DE combined with various chemical insecticides (Kavallieratos et al. 2009).
In current study, the efficacy of certain control agents that affected by different parameters like concentration rate, insect species, grain type, time for storage and application method of combined form was studied.

\section{Methods}

The current study was conducted at the College of Agriculture, Bahauddin Zakariya University, Bahadur SubCampus Layyah Punjab Pakistan. DE, DEBBM and fungus (Beauveria bassiana) with different concentrations against Cryptolestes ferruginous, Rhyzopertha dominica and Tribolium castaneum.

\section{Collection of insects}

Insect species (C. ferruginous, $R$. dominica and T. castaneum) were collected from different godowns of stored grains in district Layyah.

\section{Grain commodities}

The grains used in this trial were free of chemicals and pests infestation from Wheat (var. galaxy-2013), Rice (var. Basmati-2011) and Maize (var. DK-6142). By using the Dickey-John moisture meter we measured the percentage of moisture present in the grains. The moisture present in wheat grains was $10.95 \%$ and in rice was $9.97 \%$ and $11.17 \%$ in maize.

\section{Diatomaceous earth and DEBBM formulation}

The diatomaceous earth (DE) formulation used in the tests was DEBBM (Diatom Research and Consulting Inc., Guelph, ON, Canada). The DE constituent, which is 90\% of the formulation, is from the group of fresh water DEs and is composed of $89 \%$ amorphous $\mathrm{SiO}_{2}, 4 \% \mathrm{Al}_{2} \mathrm{O}_{3}$, $1.7 \% \mathrm{Fe}_{2} \mathrm{O}_{3}, 1.4 \% \mathrm{CaO},>1 \% \mathrm{MgO}+\mathrm{K}_{2} \mathrm{O}$ and $3 \% \mathrm{H}_{2} \mathrm{O}$. The remaining $0.05 \%$ active ingredient is Chinese plant extract (bitter barkomycin). Formulation of DE (150 mg/ $\mathrm{kg})$ and DEBBM $(50 \mathrm{mg} / \mathrm{kg})$ was used against test insect.

\section{Collection of Beuveria bassiana}

Pure culture of $B$. bassiana was taken from the first fungal culture bank of PIAS, University of the Punjab, Lahore, Pakistan. Where the pathogenicity of fungi was tested against $C$. ferruginous as described by Freeman et al. (1998) and Twizeyimana et al. (2013) in laboratory and culture was maintained in the Plant Pathology Laboratory of College of Agriculture, BZU, Bahadur campus Layyah.

\section{Collection of spores of $B$. bassiana}

One liter distilled water and 40 g PDA (Potato Dextrose Agar) was boiled in a flask till dissolved entirely. The solution was autoclaved at $120{ }^{\circ} \mathrm{C}$ for $30 \mathrm{~min}$. Spores of fungi were inoculated on PDA medium aseptically, and 
Table 1 Mortality (\%) of Cryptolestes ferrugineus in various commodities treated with DE, DEBBM and Beauveria bassiana applied sole or in combination

\begin{tabular}{|c|c|c|c|c|c|c|c|c|c|}
\hline \multirow{2}{*}{$\begin{array}{l}\text { Exposure } \\
\text { Interval } \\
\text { days }\end{array}$} & \multicolumn{9}{|c|}{ Commodity Mortality \% at concentrations of B. bassiana (conidia $\left.\mathrm{kg}^{-1}\right), \mathrm{DE} / \mathrm{DEBBM}(\mathrm{mg} / \mathrm{kg}$ ) } \\
\hline & & $1.5 \times 10^{8} / 0 / 0$ & $1.5 \times 10^{10} / 0 / 0$ & $0 / 150 / 0$ & $0 / 0 / 50$ & $1.5 \times 10^{8}$ & $1.5 \times 10^{1 c}$ & $1.5 \times 10^{8}$ & $1.5 \times 10^{10} / 0 / 50$ \\
\hline \multirow[t]{3}{*}{7} & Maize & $26.23 a$ & $51.64 b-d$ & $45.45 b c$ & $60.26 c-e$ & $42.10 a b$ & $66.29 a b$ & $56.30 \mathrm{~b}-\mathrm{e}$ & $74.21 \mathrm{e}$ \\
\hline & Rice & $31.11 \mathrm{a}$ & $57.54 b-d$ & $53.36 \mathrm{a}-\mathrm{c}$ & $61.32 \mathrm{~cd}$ & 44.19ab & $73.15 d$ & $61.30 b-d$ & $77.18 d$ \\
\hline & Wheat & $35.12 \mathrm{a}$ & $68.26 b-d$ & $53.18 b c$ & $71.02 \mathrm{~cd}$ & $48.14 a b$ & $75.37 d$ & $64.20 b-d$ & $77.12 d$ \\
\hline \multirow[t]{3}{*}{14} & Maize & $42.16 a$ & $61.59 \mathrm{a}-\mathrm{d}$ & $53.28 \mathrm{a}-\mathrm{c}$ & $72.32 \mathrm{c}-\mathrm{e}$ & $50.36 a b$ & $81.40 \mathrm{de}$ & $66.10 b-d$ & $91.18 \mathrm{e}$ \\
\hline & Rice & $48.26 a$ & $68.20 \mathrm{a}-\mathrm{c}$ & $63.21 \mathrm{a}-\mathrm{c}$ & $77.52 \mathrm{~cd}$ & $56.36 a b$ & $88.13 \mathrm{de}$ & $69.20 b-d$ & $97.35 \mathrm{e}$ \\
\hline & Wheat & $53.15 a$ & $72.57 b-d$ & $62.21 \mathrm{a}-\mathrm{c}$ & $81.25 \mathrm{~cd}$ & $60.31 a b$ & 93.34de & $74.16 b-d$ & $100.00 \mathrm{e}$ \\
\hline \multirow[t]{3}{*}{21} & Maize & $56.24 a$ & $73.23 a-c$ & 61.16ab & $76.26 b-d$ & 61.29ab & $86.22 \mathrm{~cd}$ & $73.13 \mathrm{a}-\mathrm{c}$ & $97.55 d$ \\
\hline & Rice & $62.25 a$ & $77.67 a-c$ & 71.37ab & $83.27 b-d$ & $66.43 a b$ & $93.14 \mathrm{~cd}$ & $77.15 a-c$ & 100.00d \\
\hline & Wheat & $69.26 a$ & 80.63ab & $72.35 a b$ & $86.22 \mathrm{bc}$ & $71.24 \mathrm{a}$ & $100.00 c$ & 80.33ab & $100.00 c$ \\
\hline
\end{tabular}

Similar lettering within rows are not significantly different @ $p<0.05$

kept for incubation at $26 \pm 1{ }^{\circ} \mathrm{C}$. On culture after five days Mycelium was developed. By using Whatman Filter paper No.1, the culture was filtered. Obtained mycelium grew on filter paper. In bioassay after 25 days, the conidia collected from this mycelium were used using Hemocytometer (Murali et al. 2012).

\section{Bioassay}

\section{Mortality effect of $B$. bassiana, DE and DEBBM alone} and combined against the tested insects

One kilo gram of each grain commodities viz. wheat, rice and maize were prepared and kept in plastic jars separately. Two concentrations of B. bassiana $\left(1.5 \times 10^{8}\right.$ and $1.5 \times 10^{10}$ conidia $\mathrm{kg}^{-1}$ of grains), with DE (150 mg/ $\mathrm{kg}$ and $50 \mathrm{mg} / \mathrm{kg}$ ) and $(50 \mathrm{mg} / \mathrm{kg})$ of DEBBM alone or in combinations. One untreated lot was kept as control. Data were taken after 7,14 and 21 days to check insect mortality. The corrected mortality was calculated by using Abbott's formula (1925).

$$
\text { Corrected mortality }(\%)=\frac{M_{o}-M_{c}}{100-M_{c}} \times 100
$$

$M_{o}=$ Mortality observed, $M_{c}=$ Mortality in control.

\section{Statistical analysis}

The analysis was done with Minitab 13.2 (Minitab, 2002 Software Inc., Northampton, MA). The Tukey-Kramer (HSD) test at the 5\% significance level was used to compare the means of adult mortality (Sokal and Rohlf 1995).

\section{Results}

Applied treatments along with their exposure time exhibited maximum mortality of $C$. ferrugineus on wheat, followed by maize. Mortality percentages were ranged between 45 and $72 \%$ where DE alone was applied, at the end of the trial, and application of DEBBM alone exhibited mortality between 60 and $87 \%$. A combination of DE with a high concentration of $B$. bassiana exhibited mortality between 66 and 100\%, while DEBBM and B. bassiana (high concentration) showed mortality between 74 and $100 \%$ at the end of the trial (Table 1 ).

The mortality of $R$. dominica was maximum on wheat as compared to maize and rice. In all cases, sole application of DE caused mortality between 39 and 67\%, after 21 days of treatment, and DEBBM exhibited a high mortality between 50 and $84 \%$. Application of DE and DEBBM with a high concentration of B. bassiana $\left(1.5 \times 10^{10}\right.$ conidia $\mathrm{kg}^{-1}$ of grains) exerted more impact on mortality as compared to their sole application. The combined application of DEBBM with B. bassiana (high concentration) exhibited high mortality (68-100\%), while $\mathrm{DE}$ with a high concentration of $B$. bassiana showed mortality between 60 and $96 \%$ after 21 days of treatments (Table 2).

Maximum mortality of T. castaneum was assessed on wheat followed by rice and maize. Regarding alone treatment application, DE exhibited mortality between 32 and $61 \%$ and DEBBM showed mortality between 45 and $78 \%$. Among all cases except one, B. bassiana application with its high concentration exhibited maximum mortality as compared to lower dose application. Maximum mortality rate (56-100\%) was observed where DEBBM was applied with a high concentration of $B$. bassiana as compared to $B$. bassiana (high concentration) alone. DE application with $B$. bassiana (high concentration $1.5 \times 10^{10}$ conidia $\mathrm{kg}^{-1}$ of grains), after 21 days post treatment, showed mortality between 74 and $87 \%$, while B. bassiana (high concentration) with DEBBM exhibited mortality between 88 and $100 \%$ (Table 3 ). 
Table 2 Mortality (\%) of Rhyzopertha dominica in various commodities treated with DE, DEBBM and Beauveria bassiana applied sole or in combination

\begin{tabular}{|c|c|c|c|c|c|c|c|c|c|}
\hline \multirow{2}{*}{$\begin{array}{l}\text { Exposure } \\
\text { interval } \\
\text { days }\end{array}$} & \multicolumn{9}{|c|}{ Commodity Mortality $\%$ at concentrations of $B$. bassiana $\left(\right.$ conidia $\mathrm{kg}^{-1}$ ), DE/DEBBM (mg/kg) } \\
\hline & & $1.5 \times 10^{8} / 0 / 0$ & $1.5 \times 10^{10} / 0 / 0$ & $0 / 150 / 0$ & $0 / 0 / 50$ & $1.5 \times 10^{8}$ & $1.5 \times 10^{11}$ & $1.5 \times 10^{8} /$ & $1.5 \times 10^{10} / 0 / 50$ \\
\hline \multirow[t]{3}{*}{7} & Maize & $22.32 \mathrm{a}$ & $44.67 \mathrm{bc}$ & $39.11 \mathrm{ab}$ & $50.19 b-d$ & $34.28 a b$ & $60.11 \mathrm{~cd}$ & $43.13 b c$ & $68.20 d$ \\
\hline & Rice & $28.23 a$ & $51.11 \mathrm{~b}-\mathrm{d}$ & 44.25ab & $55.78 b-d$ & 36.33ab & $64.71 \mathrm{~cd}$ & $49.39 a-c$ & $72.23 d$ \\
\hline & Wheat & $31.75 a$ & $56.80 b-d$ & $48.88 \mathrm{a}-\mathrm{c}$ & $63.17 c-e$ & $41.28 \mathrm{ab}$ & 67.89de & $55.34 \mathrm{bcd}$ & $77.32 e$ \\
\hline \multirow[t]{3}{*}{14} & Maize & $34.24 a$ & $62.19 c-e$ & $47.76 a-c$ & $66.82 \mathrm{de}$ & $44.23 a b$ & 74.52ef & $56.72 \mathrm{~b}-\mathrm{d}$ & $85.19 f$ \\
\hline & Rice & $43.74 a$ & $63.71 \mathrm{ab}$ & $50.63 a$ & $72.24 b c$ & $46.71 a$ & $77.72 b c$ & 59.63ab & $86.62 c$ \\
\hline & Wheat & $46.69 a$ & $67.75 b-d$ & $58.31 a-c$ & $77.12 c-e$ & $51.82 \mathrm{ab}$ & $81.55 \mathrm{de}$ & $61.39 a-c$ & $93.46 \mathrm{e}$ \\
\hline \multirow[t]{3}{*}{21} & Maize & $44.38 a$ & $65.37 \mathrm{bc}$ & 57.10ab & $76.10 \mathrm{~cd}$ & $52.26 a b$ & $87.48 \mathrm{~d}$ & $68.26 b c$ & $94.33 d$ \\
\hline & Rice & $52.28 a$ & $73.75 b-d$ & $63.15 a-c$ & $79.27 a-c$ & $58.22 \mathrm{ab}$ & 92.28de & $75.21 b-d$ & $97.24 \mathrm{e}$ \\
\hline & Wheat & $56.33 a$ & $77.30 \mathrm{bc}$ & $67.36 a-c$ & $84.11 c-e$ & $62.16 a b$ & $96.17 \mathrm{de}$ & $79.37 b-d$ & $100.00 \mathrm{e}$ \\
\hline
\end{tabular}

Similar letters within rows are not significantly different @ $p<0.05$

Table 3 Mortality (\%) of Tribolium castaneum in various commodities treated with DE, DEBBM and Beauveria bassiana applied sole or in combination

\begin{tabular}{|c|c|c|c|c|c|c|c|c|c|}
\hline \multirow{2}{*}{$\begin{array}{l}\text { Exposure } \\
\text { interval } \\
\text { days }\end{array}$} & \multicolumn{9}{|c|}{ Commodity Mortality \% at Concentrations of B. bassiana (conidia $\mathrm{kg}^{-1}$ ), DE/DEBBM (mg/kg) } \\
\hline & & $1.5 \times 10^{8} / 0 / 0$ & $1.5 \times 10^{10} / 0 / 0$ & $0 / 150 / 0$ & $0 / 0 / 50$ & $1.5 \times 10^{8} / 150 / 0$ & $1.5 \times 10^{10} / 150 / 0$ & $1.5 \times 10^{8} / 0 / 50$ & $1.5 \times 10^{10} / 0 / 50$ \\
\hline \multirow[t]{3}{*}{7} & Maize & $16.22 a$ & $38.14 \mathrm{bc}$ & $32.30 \mathrm{a}-\mathrm{c}$ & $45.34 \mathrm{~cd}$ & $26.35 a b$ & $47.39 \mathrm{~cd}$ & $34.19 b c$ & $56.31 d$ \\
\hline & Rice & $22.68 \mathrm{a}$ & $41.43 a-c$ & $37.31 a-c$ & $49.34 b-d$ & $31.34 a b$ & $54.55 \mathrm{~cd}$ & $40.36 a-c$ & $64.28 d$ \\
\hline & Wheat & $25.28 \mathrm{a}$ & $47.34 \mathrm{bc}$ & $42.25 \mathrm{a}-\mathrm{c}$ & $53.25 \mathrm{~cd}$ & $34.79 a b$ & $56.12 \mathrm{~cd}$ & $45.41 \mathrm{bc}$ & $68.12 d$ \\
\hline \multirow[t]{3}{*}{14} & Maize & $29.38 a$ & $52.20 \mathrm{~cd}$ & $42.91 \mathrm{a}-\mathrm{c}$ & $55.23 \mathrm{c}-\mathrm{e}$ & $34.40 a b$ & $65.41 \mathrm{de}$ & $48.13 b-d$ & $71.18 \mathrm{e}$ \\
\hline & Rice & $32.52 a$ & $54.41 b-d$ & $47.15 b c$ & $62.01 \mathrm{c}-\mathrm{e}$ & $38.25 a b$ & 68.34de & $53.15 b-d$ & $73.48 \mathrm{e}$ \\
\hline & Wheat & $37.53 a$ & $59.38 b-d$ & $55.43 a-c$ & $63.13 \mathrm{~cd}$ & 46.21ab & 74.13de & $53.43 \mathrm{bc}$ & $83.33 e$ \\
\hline \multirow[t]{3}{*}{21} & Maize & $35.43 a$ & $61.11 b-d$ & $54.32 \mathrm{a}-\mathrm{c}$ & $66.19 \mathrm{~cd}$ & $45.25 \mathrm{ab}$ & $74.81 \mathrm{de}$ & $60.25 b-d$ & $88.20 \mathrm{e}$ \\
\hline & Rice & $43.55 a$ & $63.58 \mathrm{bc}$ & $56.50 \mathrm{ab}$ & $75.59 \mathrm{~cd}$ & 51.33ab & 84.35de & $65.41 b-d$ & $93.33 \mathrm{e}$ \\
\hline & Wheat & $48.23 a$ & $68.35 b c$ & $61.33 a-c$ & $78.25 \mathrm{~cd}$ & $56.35 a b$ & $87.35 \mathrm{de}$ & $73.38 b-d$ & 100.00e \\
\hline
\end{tabular}

Similar letters within rows is not significantly different @ $p<0.05$

\section{Discussion}

Various studies have demonstrated that insecticidal abilities of various DE preparations showed dissimilar results against specific insect species. In this illustration, three different DE formulations (Protect-It, PyriSec and Insecto) were tested on the T. confusum population that showed significant dissimilar in effectiveness of given DEs (Kavallieratos et al. 2009). Likewise, Collins and Cook (2006) assessed 2 DEs Diasecticide and SilicoSec at laboratory condition in contrast to Tribolium castaneum, Oryzaephilus surinamensis, Sitophilus granaries, Lepidoglyphus destructor, Ephestia kuehniella and mites Acarus siro, pests of the stored product and saw SilicoSec as the best product for all tested pest species. Athanassiou et al. (2004) have also described improved properties of Protect-It and PyriSec than Insecto for the reduction of Rhyzopertha dominica, Sitophilus oryzae and Tribolium castaneum stored grain pest beetles.
Overall, all the DEs have similar method of action (Korunić 2013). Therefore, the substances present in the viable DEs formulations reduced to observe efficacy changes among several formulations. In the present study, 2 DEs were tested because of their differences in composition: the Protect-It comprises silica-aerogel and the DEBBM formulation of DE is improved with the bitterbarkomycin (BBM). The DEBBM showed to be much successful as to Protect-It, at least at the lowest concentration of $50 \mathrm{ppm}$, contrary to all targeted insect species present in each product type. The efficiency of DEBBM to the $R$. dominica (Wakil et al. 2011), C. ferrugineus, $T$. castaneum and S. zeamais (Athanassiou et al. 2009) have been described previously. These insect dead bodies might be served as a proper substrate in the application of fungal growth. BBM retains such antifeedant features (Wu et al. 2017) consequently, boosting mutual action of these 2 ingredients are also armored with poisonous 
effects employed by the fungus activity, which additionally destroyed the immunity system of already starving insects.

Entomopathogens showed a synergistic mode of action and can be used as a control strategy against various stored grain insect pests for their control (Akbar et al. 2004). Similarly, Master (2001) attained significant outcomes when $B$. bassiana used for controlling the grain borer. Akbar et al. (2004) studied the application of $B$. bassiana alone and in combination with Biopesticide to control T. granarium, that resulted also in line with Lord (2001) who documented its synergistic impact.

The influence of combined treatments (B. bassiana + Biopesticide) may be accredited in a way that showed no negative impact regarding conidial germination, vegetative growth and $B$. bassiana conidiogenesis (Neves et al. 2001). Alizadeh et al. (2007) documented that biopesticide (high concentration) significantly impacted mortality when used with B. bassiana. Similarly, Sheeba et al. (2001) observed the maximum $S$. oryzae mortality in a case where B. bassiana (high concentration) was used in bioassay. A high dosage of $B$. bassiana and Biopesticide significantly enhanced mortality when used against $C$. ferrugineus and $R$. dominica. Various insecticides viz. pyrethroids (Athanassiou et al. 2004) and microbial sprays (Vayias et al. 2009) impacted mortality concerning their concentration.

The current study revealed that mortality is directly proportional to the prolonged exposure time. Results of current trials are also in accordance with previous studies (Wakil et al. 2012). Various factors viz. surface to volume ratio, concentrations, application time and exposure length impacts insect pest susceptibility (Mewis and Ulrichs 2001). Enhanced application of biopesticides increases the strength of B. bassiana, after 14 days, and impact is enhanced more with prolonged time of exposure against insect pests (Michalaki et al. 2007).

\section{Conclusions}

It was concluded that DEBBM along with B. bassiana high concentration showed maximum impact regarding to mortality of the tested insect pests. While the present trial signifies the outcomes only in-vitro studies. Moreover, future studies are essential as in-vivo environment for the expansion of an effective, non-hazardous and IPMcompatible control measure of the tested insect pests in stored commodities.

\section{Abbreviations}

DE: Diatomaceous earth; Mo: Mortality observed; Mc: Mortality in control; SE: Standard Error.
Acknowledgements

We are very thankful to the Plant Pathology and Entomology Laboratory at College of Agriculture, BZU, Bahadur Sub Campus, Layyah, Punjab, Pakistan which provide us technical help in this research.

\section{Authors' contributions}

Ch. Muhammad Shahid Hanif, Hafiz Muhammad Aatif, Muhammad ljaz: Planned the research; Kamran Ikram, Azhar Abbas Khan, Muhammad Ismail, Muhammad Ashir: Carried out all the experiment including the bioassay tests and analytical part; Muhammad Zeeshan Mansha, Qamar uz Zaman: Analysis of data and wrote the manuscript. All authors read and approved the final manuscript

\section{Funding}

The study was conducted with the available laboratory resources without any aid from any funding agency.

Availability of data and materials

All the study data have been presented in the manuscript, and high-quality analytical grade materials were used in this study.

\section{Declarations}

Ethics approval and consent to participate

Not applicable.

Consent for publication

This study does not contain any individual person's data.

\section{Competing interests}

The authors have no competing interests.

\section{Author details \\ ${ }^{1}$ College of Agriculture, Bahauddin Zakariya University, Bahadur Sub Campus, Layyah 31200, Punjab, Pakistan. ${ }^{2}$ Department of Environmental Sciences, The University of Lahore, Lahore, Pakistan. ${ }^{3}$ Department of Agricultural Engineer- ing, KFUEIT, Rahim Yar Khan, Punjab, Pakistan.}

Received: 18 November 2021 Accepted: 6 February 2022

Published online: 13 February 2022

\section{References}

Abbott WS (1925) A method of computing the effectiveness of an insecticide. J Econ Entomol 18(2):265-267

Ahmed A, Ahmad T, Arian MA, Ahmed M (2008) Management of bagged wheat godowns to control the stored grain insect pests. Pak Entomol 30:31-35

Akbar W, Lord JC, Nechols JR, Howard RW (2004) Diatomaceous earth increases the efficacy of Beauveria bassiana against Tribolium castaneum larvae and increases conidia attachment. J Econ Entomol 97(2):273-280. https://doi.org/10.1603/0022-0493-97.2.273

Alizadeh A, Samih MA, Khezri M, Riseh RS (2007) Compatibility of Beauveria bassiana (Bals.) Vuill. With several pesticides. Int J Agric Biol 9:31-34

Arthur FH (1996) Grain protectants: current status and prospects for the future. J Stor Prod Res 32:293-302

Athanassiou CG, Kavallieratos NG, Andris NA (2004) Insecticidal effect of three diatomaceous earth formulations against adults of Sitophilus oryzae (Coleoptera: Curculionidae) and Tribolium confusum (Coleoptera: Tenebrionidae) on oat, rye and triticale. J Econ Entomol 97:2160-2167. https://doi.org/10.1093/jee/97.6.2160

Athanassiou CG, Korunic Z, Vayias BJ (2009) Diatomaceous earths enhance the insecticidal effect of bitterbarkomycin against stored-grain insects. Crop Prot 28:123-127. https://doi.org/10.1016/j.cropro.2008.09.012

Athanassiou CG, Arthur FH, Throne JE (2011) Efficacy of layer treatment with methoprene for control of Rhyzopertha dominica (Coleoptera: Bostrychidae) on wheat, rice and maize. Pest Manag Sci 67:380-384 
Bounechada M, Doumandji SE (2004) Effect of Ocneridia volxemi Bolivar (Pamphaginae, Orthoptera) hoppers and adults by Beauveria bassiana conidia in an oil formulation. Agric Appl Bio Sci 69:211-218

Chaudhry FM (1994) Kharif cereal crops. In: Bashir E, Bantel R (eds) Crop production. NBF, Islamabad

El-Sharabasy HM (2015) Laboratory evaluation of the effect of the entomopathogenic fungi, Hirsutella thompsonii and Paecilomyces fumosoroseus, against the citrus brown mite, Eutetranychus orientalis (Acari: Tetranychidae). Plant Prot Sci 5:39-45. https://doi.org/10.17221/ 72/2014-PPS

Freeman S, Katan T, Shabi E (1998) Characterization of Colletotrichum species responsible for anthracnose diseases of various fruits. Plant Dis 82(6):596-605. https://doi.org/10.1094/PDIS.1998.82.6.596

Goettel MS, Eilenberg J, Glare TR (2005) Entomopathogenic fungi and their role in regulation of insect populations, In: Gilbert LI, latrou K, Gill S [ed], Comprehensive Molecular Insect Science, Volume 6. Pergamon Press, Oxford, UK

GOP (2003) Economic Survey 2002-03, Finance Division, Economic Advisor's Wing, Islamabad, Government of Pakistan. Available Online http://www. irispunjab.gov.pk/StatisticalReport/Pakistan\%20Economic\%20Surveys/ Pakistan\%20Economic\%20Survey\%202003-04.pdf. Last Accessed on 22 April 2021

Holder DJ, Keyhani NO (2005) Adhesion of the entomopathogenic fungus Beauveria bassiana (Cordyceps) to substrata. Appl Environ Microbiol 71:5260-5266. https://doi.org/10.1128/AEM.71.9.5260-5266.2005

Irshad MA, Baloch UK, Irshad M, Khan A (1988) Losses in wheat in public sector storage in Rawalpindi region during 1984-85. Pak J Agri Res 9:136-140

Jilani G (2007) Postharvest protection of food grains with natural insect repellents. Prog Farm 1:26-29

Karunakaran C, Jayas DS, White NDG (2004) Identification of wheat kernels damaged by the red flour beetle using X-ray image. Biosyst Eng 87(3):267-274

Kavallieratos NG, Athanassiou CG, Vayias BJ, Mihail SB, Tomanović Z (2009) Insecticidal efficacy of abamectin against three stored-product insect pests: influence of dose rate, temperature, commodity, and exposure interval. J Econ Entomol 102:1352-1359. https://doi.org/10.1603/029.102. 0363

Khan I, Afsheen S, Din N, Khattak S, Khalil SK, Lou YHY (2010) Appraisal of different wheat genotypes against angoumois grain moth, Sitotroga ceralella (oliv). Pak J Zool 42:161-168

Korunić Z (2013) Diatomaceous earths-natural insecticides. Pesticides Phytomedicine (belgrade) 28(2):77-95

Lord JC (2001) Desiccant dusts synergise the effect of Beauveria bassiana (Hyphomycetes: Moniliales) on stored-grain beetles. J Econ Entomol 94:367-372. https://doi.org/10.1603/0022-0493-94.2.367

Mason LJ (2003) Grain insect fact sheet E-227-W: Rusty, flat and flour mill beetles Cryptolestes spp. Department of Entomology, Purdue University

Mewis II, Ulrich C (2001) Action of Amorphous Diatomaceous earths against different stages of stored Product Pests Tribolium confusum, Tenebrio molitor, Sitophilus granarius and Plodia interpunctella. J Stor Prod Res 37:153-164. https://doi.org/10.1016/s0022-474x(00)00016-3

Michalaki MP, Athanassiou CG, Steenberg T, Buchelos CT (2007) Effect of Paecilomyces fumosoroseus (Wise) Brown and Smith (Ascomycota: Hypocerales) alone or in combination with diatomaceous earth against Tribolium confusum Jacquelin du Val (Coleoptera: Tenebrionidae) and Ephestia kuehniella Zeller (Lepidoptera: Pyralidae). Biol Control 40:280-286. https:// doi.org/10.1016/j.biocontrol.2006.09.003

Murali M, Amruthesh KN, Sudisha J, Niranjana SR, Shetty HS (2012) Screening for plant growth promoting fungi and their ability for growth promotion and induction of resistance in pearl millet against downy mildew disease. J Phyto 4:30-36

Neves PMOJ, Hirose E, Tchujo PT, Moino AJ (2001) Compatibility of entomopathogenic fungi with neonicotinoid insecticides. Neotropical Entomol 30:263-268. https://doi.org/10.1590/S1519-566X20010002000 09

Pacheco IA, Sartori MR, Taylor RWD (1990) Levantamento de resistência de insetos-praga de grãos armazenados à fosfina, no estado de São Paulo. Coletânea do ITAL 20:144-154

Riasat T, Wakil W, Ashfaq M, Sahi ST (2011) Effect of Beauveria bassiana mixed with diatomaceous earth on mortality, mycosis and sporulation of
Rhyzopertha dominica on stored wheat. Phytoparasitica 39:325-331. https://doi.org/10.1007/s12600-011-0164-6

Sheeba G, Seshardi S, Raja N, Janarthanan S, Ignacimuthu S (2001) Efficacy of Beauveria bassiana for control of the rice weevil Sitophilus oryzae (L.) (Coleoptera: Curculionidae). Appl Entomol Zool 36:117-120. https://doi. org/10.1303/aez.2001.117

Shuaib M, Zeb A, Ali Z, Ali W, Ahmad T, Khan I (2007) Characterization of wheat varieties by seed storage protein electrophoresis. Afr J Biotechnol 6(5):497-500

Sokal RR, Rohlf FJ (1995) Biometry: the principles and practice of statistics in biological research, 3rd edition. W.H. Freeman and Co., New York. ISBN-13: 978-0716724117

Srivastava CN, Maurya P, Sharma P, Mohan L (2009) Prospective role of insecticides of fungal origin: review. Ento Res 39:341-355. https://doi.org/10. 1111/j.1748-5967.2009.00244.x

Stricker AR, Grosstessner-Hain K, Würleitner E, Mach RL (2006) Xyr1 (Xylanase Regulator 1) regulates both the hydrolytic enzyme system and D-Xylose metabolism in Hypocrea jecorina. Eukaryot Cell 5:2128-2137. https://doi. org/10.1128/EC.00211-06

Twizeyimana M, Förster H, McDonald V, Wang DH, Adaskaveg JE, Eskalen A (2013) Identification and pathogenicity of fungal pathogens associated with stem-end rot of avocado in California. Plant Dis 97(12):1580-1584. https://doi.org/10.1094/PDIS-03-13-0230-RE

Vayias BJ, Athanassiou CG, Buchelos CTh (2009) Effectiveness of Spinosad combined with diatomaceous earth against different European strains of Tribolium confusum duVal (Coleoptera: Tenebrionidae): influence of commodity and temperature. J Stored Prod Res 45:165-176. https://doi.org/ 10.1016/j.jspr.2008.11.002

Viñuela E, Jacas JA, Marco V, Adan A, Budía F (1993) Los efectos de los plaguicidas sobre los organismos beneficiosos en agricultura. Grupo de trabajo deOILB laguicidas y organismos beneficiosos. I Insecticidas y Acaricidas Phytoma 45:18-25

Wakil W, Riasat T, Ghazanfar MU, Kwon YJ, Shaheen FA (2011) Aptness of Beauveria bassiana and enhanced diatomaceous earth (DEBBM) for control of Rhyzopertha dominica F. Entomol Res 41:233-324. https://doi.org/10. 1111/j.1748-5967.2011.00342.x

Wakil W, Riasat T, Ashfaq M (2012) Residual efficacy of thiame-thoxam, Beauveria bassiana (Balsamo) Vuillemin, and diatomaceous earth formulation against Rhyzopertha dominica F. (Coleoptera: Bostrychidae). J Pest Sci 85:341-350. https://doi.org/10.1007/s10340-011-0408-8

Wu Y, Guo S, Huang D, Wang C, Wei J, Li Z, Du S (2017) Contact and repellant activities of zerumbone and its analogues from the essential oil of Zingiber zerumbet (L.) Smith against Lasioderma serricorne. J Oleo Sci 66(4):399-405. doi:https://doi.org/10.5650/jos.ess16166

Ye G, Xiao Q, Chen M, Chen X, Yuan Z, Stanley D (2014) Tea: biological control of insect and mite pests in China. Biol Control 68:73-91. https://doi.org/ 10.1016/j.biocontrol.2013.06.013

\section{Publisher's Note}

Springer Nature remains neutral with regard to jurisdictional claims in published maps and institutional affiliations.

\section{Submit your manuscript to a SpringerOpen ${ }^{\circ}$ journal and benefit from:}

- Convenient online submission

- Rigorous peer review

- Open access: articles freely available online

- High visibility within the field

- Retaining the copyright to your article

Submit your next manuscript at $\boldsymbol{\nabla}$ springeropen.com 